\title{
Interactive comment on "Simulating human impacts on global water resources using VIC-5" by Bram Droppers et al.
}

\section{Bram Droppers et al.}

bram.droppers@wur.nl

Received and published: 6 March 2020

\section{Dear referee,}

Thank you very much for reviewing our paper titled "Simulating human water impacts on global water resources using VIC-5" and for your valuable comments and suggestions.

Please find our response in the attached pdf.

Sincerely, Bram Droppers on behalf of all co-authors

Please also note the supplement to this comment: https://www.geosci-model-dev-discuss.net/gmd-2019-251/gmd-2019-251-AC2supplement.pdf 
Interactive comment on Geosci. Model Dev. Discuss., https://doi.org/10.5194/gmd-2019-251, 2019.
GMDD

Interactive

comment 